\title{
Learning to Read Talmud: What It Looks Like and How It Happens
}

\section{Jane L. Kanarek and Marjorie Lehman}

Sparked by an intensification of interest in the study of talmudic literature, we are experiencing a revolution in the teaching of Talmud and rabbinic texts in North America. ${ }^{1}$ While the teaching of talmudic literature has long been a focus in Jewish religious institutions, the types of institutions offering courses in rabbinic literature and the range of adults studying it have grown exponentially in recent years. Talmud is now taught in secular universities and in adult education courses to undergraduate students as well as to rabbisin-training. Recognizing this expansion in interest, audience, and pedagogical potential, this book, Learning to Read Talmud: What It Looks Like and How It Happens, represents both a response to and a search for enriched pedagogical methods, using a series of classroom studies by professors of talmudic literature that reveal both how teachers teach their students to read and how students learn to read the Talmud. These studies analyze the teaching of Talmud to adults in a range of North American settings of higher education, ${ }^{2}$ from seminaries to secular universities and from novices to advanced students.

1 This book focuses on the teaching of the Babylonian Talmud, or Bavli, a corpus of literature composed between the third and seventh centuries in Sassanian Persia (modern-day Iraq). We have included one chapter that discusses the teaching of Mishnah, the foundational work of rabbinic literature and around which the Bavli is organized. The Mishnah was edited circa $200 \mathrm{CE}$ in the Land of Israel. The term sugya refers to a smaller unit of literary discourse within the Bavli, which is often composed of a web of various voices from different time periods.

2 One author, Sarra Lev, taught her course in a Jerusalem yeshiva (a religious institution for the study of rabbinic texts). As her students were all North American, we include her within this group. For an examination of her teaching at the Reconstructionist Rabbinical College, see "Teaching Rabbinics as an Ethical Endeavor and Teaching Ethics as a 
Through analyzing an array of teaching and learning practices, we elucidate a broad expanse of conceptual ideas and practical tools that will aid other teachers who similarly seek to teach their students how to read the Talmud using tools that encourage student investment in learning. As such, we address a known shortage in published descriptive material that articulates and analyzes what teachers do in order to effectively teach their students to read this significant literary corpus. ${ }^{3}$ To clarify the teaching goals with which we are concerned, we have structured this book around three main questions: (1) What does it mean for students to learn to read Talmud? (2) How do we, as teachers, help them learn how to read? (3) What does learning to read look like when it happens?

This contribution to expand the burgeoning field of Talmud and pedagogy breaks new ground. Specifically, Learning to Read Talmud: What it Looks Like and How it Happens is the first book to present a series of extended inquiries into the teaching of Talmud. As the following chapters demonstrate, each contributor participates and investigates a tradition of practitioner inquiry or performs practitioner research into their own teaching method. ${ }^{4}$

Rabbinic Endeavor," in Turn It and Turn It Again: Studies in the Teaching and Learning of Classical Jewish Texts, ed. Jon A. Levisohn and Susan P. Fendrick (Brighton: Academic Studies Press, 2013), 388-414.

3 See, for example, our own work, Jane Kanarek and Marjorie Lehman, "Making a Case for Rabbinic Pedagogy," in The International Handbook of Jewish Education, ed. Lisa Grant and Alex Pomson (New York: Springer, 2011), 581-96; Jane Kanarek, "The Pedagogy of Slowing Down: Teaching Talmud in a Summer Kollel," Teaching Theology and Religion 13, no. 1 (2010): 15-34; reprinted as "The Pedagogy of Slowing Down: Teaching Talmud in a Summer Kollel," in Levisohn and Fendrick, Turn It and Turn It Again. See also Marjorie Lehman, "Examining the Role of Gender Studies in the Teaching of Talmudic Literature," Journal of Jewish Education 72, no. 2 (2006): 109-21; Jeffrey Kress and Marjorie Lehman, "The Babylonian Talmud in Cognitive Perspective: Reflections on the Nature of the Bavli and Its Pedagogical Implications," Journal of Jewish Education, 69, no. 2 (2003): 58-78; and Jeffrey Kress and Marjorie Lehman, "Dialogue and 'Distance': Cognitive-Developmental Theories and the Teaching of Talmud," with Jeffrey Kress. Jewish Education News (Spring 2004): 21-23. See also Jon A. Levisohn, "A Menu of Orientations to the Teaching of Rabbinic Literature," Journal of Jewish Education, 76, no. 1 (2010): 4-51; reprinted as "What are the Orientations to the Teaching of Rabbinic Literature," in Levisohn and Fendrick, Turn It and Turn It Again.

4 On the terminology of practitioner, inquiry, or practitioner research, see Marilyn Cochran-Smith and Susan L. Lytle, Inside/Outside: Teacher Research and Knowledge (New York: Teachers College Press, 1993) and Marilyn Cochran-Smith and Susan L. Lytle, preface to Inquiry as Stance: Practitioner Research for the Next Generation (New York: Teachers College Press, 2009), viii-ix. K. Patricia Cross and Mimi Harris Steadman 
All of the chapters here reflect the work of trained scholars in the field of Talmud, accustomed to researching Talmud, rabbinic culture, and Judaism in late antiquity. Together we have undertaken a different form of research, in which the objects of research are our own teaching and our own students' learning of Talmud. We are passionate scholars of Talmud, engaged in trying to understand the past as we seek to translate it for and with our present-day students. Yet, as academics, we are often charged and motivated with furthering the scholarly agendas of the field of Talmud rather than focusing on our pedagogical aims. ${ }^{5}$ This project aims to reset if not align that balance. Not only do we see the teaching of Talmud by scholars of Talmud as a central academic endeavor, but we also believe that thinking about the Talmud as scholars is fundamentally the same as thinking about teaching Talmud. ${ }^{6}$

As scholars who have invested a considerable amount of time in learning how to read the Talmud and who are intimately familiar with what makes the

term this method "Classroom Research" and define it "as ongoing and cumulative intellectual inquiry by classroom teachers into the nature of teaching and learning in their own classrooms." K. Patricia Cross and Mimi Harris Steadman, preface to Classroom Research: Implementing the Scholarship of Teaching (San Francisco: Jossey-Bass Publishers, 1996), xviii. See also Going Public with Our Teaching: An Anthology of Practice, whose editors contend that teacher-research into their own practices can serve as the basis for local theories that then become, "a powerful knowledge base different from-but no less important than - the knowledge bases that [have] emerged from conventional research on teaching and learning." Going Public with Our Teaching: An Anthology of Practice, Thomas Hatch, et al. ed. (New York: Teachers College Press, 2005), 2.

5 See Jonah Chanan Steinberg, "Academic Study of the Talmud as a Spiritual Endeavor in Rabbinic Training: Delights and Dangers," in Levisohn and Fendrick, Turn It and Turn It Again, 377-87. In this chapter, Steinberg discusses the challenges faced by the teachers of rabbis who are trained as academics, but who also are responsible for shepherding people on their spiritual journeys. He argues that the students learn that they can engage with their most challenging questions "over and around and through" classical Jewish texts (ibid., 377).

6 See Mary Taylor Huber's discussion of Brian P. Coppola's teaching chemistry at the University of Michigan in her book Balancing Acts: The Scholarship of Teaching and Learning in Academic Careers (Washington, DC: American Association for Higher Education and The Carnegie Foundation for the Advancement of Teaching, 2004), 74 and Lee S. Shulman, "Teaching as Community Property: Putting an End to Pedagogical Solitude," Change 25, no. 6 (1993): 7, each of whom stresses the importance of reconnecting teaching to the disciplines. See also Michael Chernick, "Neusner, Brisk and the Stam: Significant Methodologies for Meaningful Talmud Study," in Levisohn and Fendrick, Turn It and Turn It Again, 105-26. 
Talmud the multivalent document that it is, we are particularly well-suited to explore the pedagogical process of and objectives in teaching Talmud. Those with expertise and more formal training in educational research certainly can and should contribute to understanding better how students learn to read Talmud. As talmudic "insiders" with rigorous training in this discipline, we are also well-prepared for this enterprise. Our understanding of both what the Talmud is and the vast range of approaches useful for reading it open up the possibility of our being both uniquely reflective teachers of this document as well as thoughtful researchers of our teaching and the learning processes of our students. We know when our students are reading with the aims we have in mind. As articulated by K. Patricia Cross and Mimi Harris Steadman, "Teachers who know their discipline and the problems of teaching it to others are in the best position to make systematic observations and to conduct ongoing investigations into the nature of learning and the impact of teaching upon it."

As Talmudists, we speak the language of other Talmudists. We are rooted in the research traditions that define us as scholars of our disciplinescholarship that we apply in the classroom to teach our students to read Talmud. ${ }^{8}$ We hope that this commonality of discipline will encourage other scholars in the field of rabbinics to become both active researchers of the Talmud and of their teaching methods. As such, this book, while focused on excellent classroom teaching that is carefully prepared and well-designed, is also about teaching that involves inquiry into a type of learning that emerges from the very nature of the text in question. ${ }^{?}$

7 Cross and Steadman, Classroom Research, xviii. See also Pat Hutchings, who comments on "the power of the disciplinary context in shaping the way faculty think about and design their approaches to the scholarship of teaching and learning," in her article "Introduction: Approaching the Scholarship of Teaching and Learning," in Opening Lines: Approaches to the Scholarship of Teaching and Learning, ed. Pat Hutchings (Carnegie Foundation for the Advancement of Teaching, 2000), 6.

8 Huber, Balancing Acts, 23.

9 For a deeper analysis of the relationship between knowing one's discipline and the practice of teaching, see Barry Holtz, "Across the Divide: What Might Jewish Educators Learn from Jewish Scholars?” Journal of Jewish Education 72 (2006): 5-28. Citing Joseph Schwab, Holtz argues for the importance of understanding the large organizing, interpretive frames that define a field prior to making decisions about practice. The very essence of the discipline needs 
With this book and its publication, we join the growing field of the scholarship of teaching and learning (SoTL), a field that seeks to expand the research agendas of scholars in a particular discipline to include research into the teaching or learning of that discipline or both. ${ }^{10}$ Familiar with posing questions and using specific interpretive methodologies in researching the answers to these questions, we tasked the contributing authors represented here to think more self-consciously about how their students learn to read Talmud. Paralleling their own research paths in the field of Talmud, the contributors to this book began their inquiries by posing a set of questions at the beginning of the teaching semester, with the result that their classrooms became the subject of their research. ${ }^{11}$ Each author's answers were therefore grounded in his or her specific institutional context-from which grew the course-specific experiential evidence you will read here. By assuming a dual role as reflective teachers and teacher-researchers, we provide windows into our actual classrooms, into our profession, to see what our teaching practices and student learning looks, feels, and sounds like. When did our students learn to read and when not? ${ }^{12}$ Each of us believes that teaching is an inquiry into learning, and each of us has opened up our classroom for review and critique by writing about it here. ${ }^{13}$ We have designed and implemented select learning experiences, examining

to inform the practice of teaching (ibid., 10-11). See also Joseph J. Schwab, "Education and the Structure of Disciplines," in Ian Westbury and Neil J. Wilkof, Joseph J. Schwab, Science, Curriculum and Liberal Education: Selected Essays (Chicago: University of Chicago Press, 1978), 229-272.

10 In the field of Jewish studies, see Levisohn and Fendrick, Turn It and Turn It Again. See also the editors' articulation of the scholarship of teaching and learning in their introduction (SoTL), "Cultivating Curiosity about the Teaching of Classical Jewish Texts, ibid., $14-18$.

11 On the importance of beginning with questions in the scholarship of teaching and learning, see Hutchings, Opening Lines, 3-6.

12 For further on this topic, see Elie Holzer and Orit Kent, A Philosophy of Havruta: Understanding and Teaching the Art of Text Study in Pairs (Boston: Academic Studies Press, 2014), 26-27. The authors also designed a program dedicated to teaching Talmud through havruta learning and then studied their own practice and their students' learning.

13 Huber, Balancing Acts, 23; Hutchings and Shulman, "The Scholarship of Teaching: New Elaborations, New Developments," 13. 
how well our students responded. ${ }^{14}$ We have charted the discussions that ensued in class each week by keeping extensive teaching journals; we have experimented with different types of assignments and then evaluated our students' work; we have audio recorded and taken videos of our classes, analyzing each record as evidence. This close attention to detail represents an integration of content and pedagogy, of scholarship and practice.

In presenting a range of perspectives on what it means to read a talmudic text, the chapters in this book highlight the distinct challenges of teaching instructional courses centered on this classical Jewish canon. Our exploration of a select array of our own teaching practices, coupled with the variety of assessments used to determine whether our students achieved the goals we each had set for them, created a framework for understanding the different types of choices we make as contingent on the contexts in which we teach our courses and the nature of the students we encounter. For example, Elizabeth Shanks Alexander, who teaches an undergraduate course at the University of Virginia to students who had never been exposed to the Talmud, worked only with translated texts and emphasized the importance of attention to detail in comprehending talmudic material, even when reading translations. Jonathan Milgram, who similarly taught an undergraduate course but at the Jewish Theological Seminary to students who could read Hebrew, emphasized the importance of the oral repetition of the Hebrew/Aramaic talmudic text in learning to read.

As a result, these eight chapters highlight a collection of focused, pragmatic teaching strategies, each informed by a set of different epistemological, religious, and political stances as well as different educational goals. We have long dismissed the idea that there is one best successful method of teaching Talmud or one best approach to reading, as the variables that have an impact on teachers' reading goals and student comprehension are numerous. These chapters reinforce the concept that students of Talmud do not learn to read in a linear fashion. The chapters also importantly add to the literature on the scholarship of teaching in describing these distinct practices, cultivated by

14 Huber, Balancing Acts, 27-28. 
the authors' different reading goals. Taken collectively, they show that studying one's teaching practices has a profound influence by creating a context "in which students engage in productive learning activities with greater intensity or focus than previously."15 Actively turning our classrooms into sites for our research made us better teachers and our students better learners. ${ }^{16}$

The chapters in this book explore aspects of learning how to read that are highly particular to understanding Talmud: its complex manner of expression in Hebrew/Aramaic, its dialogical nature where challenges are posed and refuted, its integration of source material from different historical time periods, and its centuries-old history of commentary. The vastly different preconceptions that students—-from the seminary to the secular university—bring to Talmud study also add a layer of complexity to learning to read this document. Yet, while we write here about the peculiarities and particularities of teaching the primary text of Talmud, we also contribute to a larger conversation within general education of how students learn to read primary texts, whether historical, philosophical, religious, or scientific. We join a broader discussion that supports students in becoming critical and proactive readers of primary material. ${ }^{17}$ Thus, while our book will be useful for teachers of Talmud in a range of settings, it can also speak to those who teach students how to read primary texts in many areas of higher education. ${ }^{18}$

15 Huber, Balancing Acts, 21 and Daniel J. Bernstein, Jessica Jonson and Karen Smith, "An Examination of the Implementation of Peer Review in Teaching," New Directions for Teaching and Learning, no. 83 (2000): 77-78.

16 By challenging ourselves to define precisely what we want to convey to our students about the Talmud and through seeing how our students learn to read, inquiry into teaching also enables us to become better practitioners of our central academic discipline, Talmud.

17 See, for example, the contribution of Samuel S. Wineberg, "On the Reading of Historical Texts: Notes on the Breach between School and Academy," American Educational Research Journal 28, no. 3 (1991): 499 and Sam Wineburg, "Reading Abraham Lincoln: An Expert/Expert Study in the Interpretation of Historical Texts," Cognitive Science 22, no. 3 (1998): 319-46.

18 While this book contains studies of teaching Talmud in higher education, its chapters can also inform teachers of younger students in Jewish Day schools, congregational schools, 


\section{Inside Our Process: Constructing the Book}

These classroom studies evolved from a research initiative supported by the Jack, Joseph and Morton Mandel Center for Studies in Jewish Education at Brandeis University that brought together eight scholars of Talmud in a year-long process to investigate their own and each other's pedagogy. This work built on a previous research project of the Mandel Center, the Initiative on Bridging Scholarship and Pedagogy in Jewish Studies (2003-2010). The Bridging project focused on the teaching of Bible and rabbinic literature in a variety of educational settings, including Jewish Day Schools, synagogue adult education contexts, seminaries, and universities. ${ }^{19}$ Our current initiative seeks to deepen the understanding of one aspect of this earlier work: the teaching of talmudic literature in higher education settings.

As part of our work lay in introducing scholars of Talmud to the scholarship of pedagogy, we brought this group of eight scholars together for two workshops at the Mandel Center, the first in December 2013, before we had taught the courses that would form the basis of our inquiries, and the second in June 2014, after we had taught them..$^{20}$ The first workshop focused on an investigation of our own reading practices: how each of us defined for ourselves what it meant to learn to read Talmud, how we think people learn to read in general, and what we thought our reading goals would be for our students in our specific Talmud courses. The second workshop, convened after we had taught our classes, was an opportunity for us to reexamine our courses within the context of the scholarship of pedagogy. These two workshops, thus, were part of a reflective process that bookended a semester of teaching. ${ }^{21}$

and non-religious schools. Of course, the practices described will have to be molded for those settings.

19 For further information on the Bridging Initiative, see "Bridging Scholarship and Pedagogy in Jewish Studies," accessed April 22, 2015, http://www.brandeis.edu/mandel/ projects/bridging/.

20 Shulman, "Teaching as Community Property," 7.

21 A longer process would likely have enabled us to deepen our reflective process and apply the insights we had gained from investigating this one course to another and then, in 
Guided by the research of Ellin Oliver Keene and Susan Zimmermann on teaching students to read, portrayed in their book Mosaic of Thought: Teaching Comprehension in a Reader's Workshop, ${ }^{22}$ we felt it essential to begin our first workshop by thinking about our own reading comprehension strategies before we could examine how we would teach reading to our students. As described by Stephanie Harvey and Anne Goudvis, Keene and Zimmermann argue that, "as the custodians of reading instruction, teachers must be readers first. Of all professionals who read, teachers must top the list." ${ }^{23}$ Whether we are teachers of undergraduates in secular universities, of rabbinical students in seminaries, of graduate students of ancient literature, or of young adults in egalitarian yeshivot, and whether our students are Jewish or non-Jewish, studied rabbinic literature previously or not-we needed to understand our own processes of proficient reading before we could attempt to think about the ways in which we wanted to teach our students to read. With this in mind, we meticulously studied a brief Talmud passage in havruta (study pairs) and then as a full group, asking everyone to read attentively in order to be able to articulate well how he or she made sense of the passage. ${ }^{24}$ We asked everyone to think about the point at which they felt they had "understood" the text—what it means to them to read a text of the Talmud proficiently.

When we reflected back on the group conversations that followed our havruta study, we were able to conclude that as proficient readers of Talmud we approach unfamiliarity, including difficult words, concepts, and ideas, with a sense of familiarity. We know when we do not comprehend something, we know why it is unclear, and we develop strategies to solve our

turn, research and evaluate that course.

22 Ellin Oliver Keene and Susan Zimmermann, Mosaic of Thought: Teaching Comprehension in a Reader's Workshop (Portsmouth, NH: 1997). This book is also available in a revised edition: Ellin Oliver Keene and Susan Zimmermann, Mosaic of Thought: The Power of Comprehension Strategy Instruction, 2nd ed. (Portsmouth, NH: Heinemann, 2007). For our workshop, we found the way in which the material was presented in the first edition to be more useful.

23 Stephanie Harvey and Anne Goudvis, Strategies that Work: Teaching Comprehension to Enhance Understanding (Portland, ME: Stenhouse, 2000), 7.

24 For a discussion on the contributions of havruta learning to learning to read Talmud, see Holzer and Kent, Philosophy of Havruta. We chose to study a passage from B. Avodah Zarah 8a. 
difficulties. For example, some of us relied on the medieval commentator Rashi (Rabbi Shlomo Yitzhaki, 1040-1105) for sense-making at the local level; others of us turned to Rashi only later in the process and instead began with dictionaries or parallel talmudic passages. ${ }^{25}$ While our individual strategies may have differed somewhat, we all modeled proficient reading. In other words, each of us could automatically activate a prior schema and use prior knowledge to solve the reading challenges and make sense of the passage in front of us.

We next turned from the specifics of our own reading processes in Talmud to thinking about learning to read in general. As we prepared for our workshop, we were surprised to find a gap in the scholarship on teaching college and graduate school students how to read. ${ }^{26}$ Unsurprisingly, however, we were able to uncover a greater amount of scholarship on teaching reading comprehension to elementary school children. ${ }^{27}$ We turned to an expert kindergarten and first-grade teacher Shira Horowitz, who has extensive experience instructing teachers on reading and teaching children how to read, including reading Jewish texts. ${ }^{28}$ Proficient readers, she pointed out, no

25 Rashi is renowned for his almost comprehensive commentary on the Babylonian Talmud. His commentary, part of the standard talmudic page, is distinguished by its attachment to the word or words being explicated as well as to the local sugya.

26 For material on teaching students to read and understand primary texts, see Robert Scholes, Textual Power: Literary Theory and the Teaching of English (New Haven: Yale University Press, 1986) and his Protocols of Reading (New Haven: Yale University Press, 1991). In both books, he discusses teaching students to read texts critically. See also Dennis Donoghue, The Practice of Reading (New Haven: Yale University Press, 1991), who argues for reading texts closely and imaginatively, without necessarily theorizing about them. And see Sophie Haroutunian-Gordon, Turning the Soul: Teaching through Conversations in the High School (Chicago: University of Chicago Press, 1991) regarding her experience teaching high school English students, stressing the importance of classroom discussion. These researchers had a great impact on the work of Holzer and Kent, as they note in their book, Philosophy of Havruta, 29-30.

27 See Keene and Zimmermann, Mosaic of Thought $(1997,2007)$ for a fuller articulation of this process and its application in teaching children to read; Harvey and Goudvis, Strategies that Work; Cris Tovani, I Read It, but I Don't Get It: Comprehension Strategies for Adolescent Readers, (Portland, ME: Stenhouse, 2000). See also Sophie HaroutunianGordon, Learning to Teach through Discussion: The Art of Turning the Soul (New Haven: Yale University Press, 2009), in which she stresses the importance of asking questions for cultivating understanding in elementary school children.

28 Shira Horowitz, “'Torah Talk': Teaching Parashat Ha-shavua to Young Children," in Levisohn and Fendrick, Turn It and Turn It Again, 324-51, where she narrates her approach to 
matter what age, are always thinking as they read, monitoring their own comprehension, and working to create new images from material that is already present in the text. She referred to this as text-to-text reading. In addition, proficient readers are adept at utilizing personal connections to their own life experiences to trigger meaning. She referred to this as textto-self. And ultimately, readers with these skills apply their ideas about how the world works to further understand what they read and to comprehend better the world around them (text-to-world). She wanted to show us that proficient readers stop and think and stop and rethink. ${ }^{29}$ Although none of us teach Talmud in precisely the step-by-step fashion that Horowitz modeled, ${ }^{30}$ this approach to reading helped us to see and articulate the necessity of breaking down our own more intuitive reading processes into their respective components, defining the process of sense-making so that we could better help our students to make sense of the Talmud. ${ }^{31}$

Once we had examined our own reading-steps and thoughts with Horowitz at the workshop about the field of elementary school teaching and how children learn to read, we then turned to the individual instances of our courses and the reading skills and strategies that we wanted our students to learn. Each of us wrote our reading goals for our own courses on large posters. As we walked around the room and read the individual list of goals each of us had authored, it quickly became apparent that while there were some overlapping reading goals, each of us had a different sense of what it meant for our students to learn how to read. There was no single overarching rubric. Every one of our approaches was intimately connected to the different contexts in which we found ourselves (for example, an undergraduate class at a seminary vs. an undergraduate class at a secular university), as well as to

teaching young children to read and understand the weekly Torah portion.

29 In fact, one of the techniques Horowitz utilizes with her students (and demonstrated for us) is a stop sign. At various points while reading a story to her students, Horowitz holds up a stop sign and asks them to pause and think about a particular question. Then she continues to read and repeats the process at select intervals. The process is meant to teach students how to "bookmark" particular details as important and to slow down the reading process in order to better help students make sense of the story.

30 See Keene and Zimmermann's Mosaic of Thought for a fuller articulation of this process and its application to elementary teaching of reading.

31 See Horowitz, "Torah Talk," 332-33 and her reference to Lucy M. Calkins, Lessons from a Child: On the Teaching and Learning of Writing (Portsmouth, NH: Heinemann, 1983). 
the different assumptions we made about what the Talmud is and why one should study it. In fact, it became clear when we returned for the second workshop that teaching students to read the Talmud was an incredibly complex process involving student, text, and teacher and included all prior experiences and expectations of both teachers and students. ${ }^{32}$ Additionally, our own scholarship and the different contributions that each of us have made to the field impacted our approaches to teaching students to read and the choices we made in the way we taught.

While the first workshop focused on thinking about the process of reading, the second workshop, which convened after we had taught our classes, focused on bringing everyone to a point where they could write the chapters that culminated in this book. To that end, we invited Jennifer Lewis, a professor of education at Wayne State University, to join our workshop. Lewis' work centers on how teachers learn about teaching and learning mathematics by researching their own teaching. Lewis had us do math problems and analyze a video of a grade-school teacher teaching those same problems-all with the goal of introducing our workshop participants to the importance of heuristically evaluating their own evidence-based research. With Lewis present, we revisited the reading goals that we had established for our courses and began to explore, based on evidence that we had gathered, what our teaching and student reading experiences looked like. For each of us, what did it mean for our students to learn how to read? How could we describe the learning processes of our students such that these processes could be duplicated by others?

\section{Inside Our Classrooms}

The chapters in this book will take you inside our classrooms and give you a remarkably close experience of a diverse range of approaches to reading. Strikingly, while some of the skills that the authors ask their respective students to master are similar, the goals of skill acquisition often differ. To be

32 This articulation is similar to the complexity of the havruta process which, as aptly described by Holzer and Kent, involves an active dialogue between the learner and text, learner and learning-partner, and each learner's preconceptions, values, and beliefs. Holzer and Kent, Philosophy of Havruta, 34-59. 
sure, all of us want more from our students and from ourselves as teachers than to have our students learn only about the Talmud. Our group was in agreement that to achieve a competence, a rich understanding of the Talmud-to understand its structure, its message, and its cultural power among Jews over the centuries — the students needed to intensively engage in reading the texts that comprise it. They needed to experience the intellectual journey on which it takes them. We shared the belief that our students would not be able to do this until they developed the skills to truly read Talmud, delving into its depth and multiple-voiced narratives, whether in translation or in Hebrew/Aramaic.

And yet, during our conferences and workshops, we learned that we approached our courses with very different reading goals, partly out of the necessity of students' desires and partly out of our own. Some of us were concerned about training rabbis to read the Talmud as a way of approaching central existential questions through a specifically Jewish lens that was simultaneously connected to a wider world of theological, philosophical, political, and emotional questions. Some of us wanted and some of our students wanted to become life-long readers of Talmud, while others of us recognized that many of our students would probably never read the Talmud again. Some of us wanted our students to value the Talmud as an essential part of a liberal arts curriculum, while others were concerned with how to read the Talmud to gain a better understanding of antiquity. Some of us hoped that reading the Talmud could make us better people and the world a better place through a commitment to reconstructive ethics. For this reason, the classroom descriptions and analyses represented in the following eight chapters provide not only examples of different teaching techniques but insight into how one teaches reading for different results. Yet, a common thread to which each contributor remained sensitive and will be observed in all of these chapters, whether the teaching context was secular or religious, is that students needed to find meaning, however differently defined, in order for them to succeed in learning to read Talmud. We therefore felt it important in presenting studies of classrooms from a range of contexts with a range of students, to highlight both what all students need to learn in order to read Talmud and what is context specific. These chapters thus question a strong dichotomy between religious and secular educational 
frameworks and suggest a softer one of overlapping but not identical processes and goals.

Beth Berkowitz, in her chapter, "Stop Making Sense: Using Text Study Guides to Help Students Learn to Read Talmud," discusses the use of a series of text study guides in a Talmud text study course taught at Barnard College. The class was composed primarily of students who had significant experience studying Talmud in high school or in a post-high school setting. However, as Berkowitz discovered, her students did more poorly on these study guides than students without previous experience in Talmud study, which seemed counter-intuitive. Berkowitz used the text study guides to invite the students to temporarily suspend their sense-making, slowing them down and preventing them from relying on what they already knew from their past experience studying Talmud. This, so they could ultimately make better sense of the text. ${ }^{33}$ Her study guides enabled students to read on three necessary levels, moving from reading for an understanding of the basic building blocks of a talmudic sugya (its vocabulary and grammar) to a recognition of the subtle shifts and textual variations that require reading on a deeper level, and finally, to reflect on their "newly made sense" of the sugya by exploring the gaps and curiosities it provoked in each of them. Berkowitz was intent on teaching her students that learning to read Talmud was about understanding the Talmud as constrained by place and time: seeing the text as grounded in a context that rendered certain interpretations implausible and others plausible. She wanted the students to understand themselves, like the rabbis, as similarly rooted; that is, simultaneously constrained in terms of their interpretive visions by the worlds they inhabit, but also as creative and imaginative thinkers. For Berkowitz, the teaching practice of requiring her students to complete extensive study guides effectively brought her students to read Talmud with this realization.

Ethan Tucker, in his chapter, "Looking for Problems: A Pedagogic Quest for Difficulties," also proposes a step-by-step process that sets students up for making sense of the talmudic sugya. While targeting the more advanced Talmud student in a North American egalitarian yeshiva,

33 For a larger discussion on the value of and strategies for slowing down, see Jane Kanarek, "The Pedagogy of Slowing Down," Teaching Theology and Religion, 15-34; reprinted as "The Pedagogy of Slowing Down," in Levisohn and Fendrick, Turn It and Turn It Again. 
Tucker contends that learning to read for difficulties involves a number of distinct steps that range from formulating a coherent reading of the talmudic passage to identifying the ways in which medieval and modern commentaries disguise problems as explanations. He begins by instructing his students to formulate a coherent reading of the chosen relevant sugya. But, as he aptly recognizes, producing a coherent reading often yields additional questions. Tucker encourages students to name these difficulties, because, as he argues, locating these difficulties is the basis for all subsequent analyses. Ultimately, Tucker's goal is to lead students to look to medieval and modern talmudic commentaries, not only to uncover the difficulties that these master readers of the Talmud encountered and to compare such questions to their own, but also to generate new challenges. Indeed, as the students learn to read through the lens of earlier expert readers and interpreters of the Talmud, they learn from them more about how to read for the dilemmas that impede sense-making in a talmudic sugya rather than solutions. Like Berkowitz, Tucker exposes, through his process of teaching the students to read for the Talmud's difficulties, something about the Talmud itself. By seeing that the discovery of difficulties in a sugya is what has defined serious Talmud study for generations, the struggles of the students to understand the texts they encounter is contextualized within a wider conversation, and a deeper purpose of the Talmud is revealed. As students learn to read with these difficulties, they come to see themselves as part of the history of talmudic interpretation, building a long-term commitment to Talmud study and a reverence for the complex language of this text as well as the struggles encountered reading it.

Jane Kanarek shares Tucker's interest in reaching outside of the talmudic sugya in order to better understand the Talmud and the problems it poses for the student of the twenty-first century. However, instead of focusing on the use of classical talmudic commentary, her chapter, "What Others Have to Say: Secondary Readings in Learning to Read Talmud," discusses the use of academic secondary readings. Teaching an intermediate level Talmud course at the Rabbinical School of Hebrew College, she proposes that integrating secondary readings, some concerned with rabbinic literature and some not, improves students' ability to decode a sugya and contributes to a richer ability to read the Talmud itself. As students learn to read scholarly articles 
along with the Bavli, students come to see the Bavli's passages as linked to a wider range of ideas in the humanities, enabling them to uncover issues that are not readily apparent (or accessible) on the surface of a talmudic sugya. These exercises empower them to engage with their own questions about meaning. As such, in learning to read the Talmud in company with the work of modern scholars, students bring their personhood back to the world of the Talmud. Students learn how to read one text critically in order to better read another.

While all of the authors represented in this book were interested in developing the personhood of their students as a part of their Talmud study, Marjorie Lehman, Gregg Gardner, and Elizabeth Alexander chose additionally to take into account their students' previous educational backgrounds in designing their courses-allowing the contrast of teaching the experienced and the novice in Talmud to be explored directly. This moving between attempts to make the familiar strange to a group of Jewish students at the Jewish Theological Seminary and attempts to make the strange familiar ${ }^{34}$ to a group of university students, who had far less exposure to talmudic texts, resulted in these scholars proposing contrasting methods of reading. For example, when teaching students how to read the Mishnah in the context of a required course for undergraduate Talmud majors at the Jewish Theological Seminary, Lehman discovered a resistance to reading the Mishnah's references to the Temple and the priesthood critically. As she notes in her chapter, "And No One Gave the Torah to the Priests: Reading the Mishnah's References to the Priests and the Temple," many students began the class thinking of the Mishnah as a testament to the rabbis, who created a type of Judaism that could function without the Temple in Jerusalem. Rabbinic Judaism, in their minds, was a natural outgrowth of Temple Judaism, a swift response to the crisis of the destruction of the Temple in $70 \mathrm{CE}$. For the undergraduate students who entered the class, references to the Temple in the Mishnah offered "true" evidence of a past Temple reality and a desire, on the part of the rabbis, to reinstate Temple life, leadership, and ritual exactly the way it had once been. Given

34 Jonathan Z. Smith, introduction to Imagining Religion: From Babylon to Jonestown (Chicago: University of Chicago Press, 1982), xiii; Jonathan Z. Smith, Relating Religion: Essays in the Study of Religion (Chicago: University of Chicago Press, 2004), 383, 389. 
this conceptual framework for reading the Mishnah, the author focused on teaching these students to read more analytically, more critically, and with greater attention to a hermeneutics of suspicion, fueled by an ability to ask questions of the texts they read. Asking the right types of questions of the mishnaic material, the author argues, is what leads the students to articulate what the rabbis were asking themselves about the Temple and their role in a world without its physical existence. The author describes her reading goal as marked by the intention to make the students' sense of the relationship of the rabbis and the Temple more complex, to make the familiar strange, by enabling the students to read the Mishnah with a far more critical eye than when they entered the course.

In his chapter, "Talmud for Non-Rabbis: Teaching Graduate Students in the Academy," Gregg Gardner argues that learning to read Talmud must be expanded to include training students how to read talmudic sources, so as to assist them in their research in other fields. Thus, when Gardner thought about the experience of teaching rabbinic literature to graduate students in classics, archaeology, and early Christianity, many of whom entered his class with little or no background in studying rabbinic literature, he had to think carefully about how to break down the barriers that prevent many from approaching this discipline altogether. The study of Talmud can be quite insular, and the obstacles preventing one's entry can be high. And yet, even what was familiar to the students (their knowledge of historical detail) became strange to them when they encountered, for example, a talmudic narrative about Rome's siege of Jerusalem, a revolt well-known to them. References to Roman emperors acting in ways that were not supported by the ancient sources with which they were familiar confused them, especially given their prior graduate training in ancient history. Gardner's appreciation of the strategies for reading proposed by Ellin Keene and Susan Zimmermann in Mosaic of Thought enabled him to apply the ways in which proficient readers read by making connections between what they know and new information that they encounter in the Talmud itself. He was concerned with teaching them to resist their desire to dismiss talmudic sources on the basis of their misuse of historical facts. For Gardner, reading the talmudic texts became an exercise in teaching his students how to read the Talmud's 
questionable historical references as literary constructions. This reading technique, which also included the ability to utilize translations in this endeavor, was central to understanding the manner in which contemporary scholars develop their arguments - without which these graduate students would be constrained in their use of talmudic texts to meaningfully illuminate their own research in the future.

For Elizabeth Shanks Alexander, the undergraduate students she taught at the University of Virginia became true partners in their own instructional process. In her chapter, "When Cultural Assumptions about Texts and Reading Fail: Teaching Talmud as Liberal Arts," she describes a process where teaching students how to read Talmud involved making them responsible for monitoring their successes, failures, and pace of their development as readers. Drawing on what L. Dee Fink identifies as six components in which one kind of learning enhances the possibility of achieving other kinds of learning, ${ }^{35}$ Alexander sought to teach her students (most of whom were reading the texts of the Talmud in translation) to "learn how to learn." This pedagogic emphasis provided an interesting hook for the students, motivating them to work with material that was difficult and unfamiliar, even when they were initially clearly discouraged. Through carefully constructed assignments that prompted students to answer questions about talmudic texts prior to going over them in class, Alexander emphasized, paralleling Tucker's observations, that reading happens, and therefore learning happens, when the students pay careful attention to difficulties, rather than skimming over them. Alexander's assignments revealed to her and to the students that they intuitively search for an overarching narrative when they read a text, often ignoring the role that textual details play in understanding a given passage with all of its nuances. Like Berkowitz, her students found that slowing down the pace of their reading was key to learning to understand a talmudic passage. Ultimately, it was about reading the Talmud to experience the intellectual thought process of the rabbis and, at the same time, to recognize that the text could become a platform for their own experiences of reading. In the

35 L. Dee Fink, Creating Significant Learning Experiences: An Integrated Approach to Designing College Courses (San Francisco: Jossey-Bass, A Wiley Imprint, 2003), 32. 
end, the students would come to recognize that their questions, just like the rabbis' questions, had many answers. Indeed, the talmudic texts could foster multiple ways of sense-making, if only one's reading was developed to recognize this.

In marked contrast, Jonathan Milgram approached teaching his students to read the Talmud by employing an ancient pedagogical approach used in the transmission of rabbinic literature-group recitation and repetition. Milgram's chapter, "Talmud in the Mouth: Oral Recitation and Repetition through the Ages and in Today's Classroom," focuses on the use of oral recitation practices in an undergraduate class at the Jewish Theological Seminary. This method, where the instructor reads the sugya aloud lineby-line in Hebrew/Aramaic, followed by class repetition, results in a greater cognitive closeness to the Talmud, due to an internalization of its rhythms. "Simulation," as Milgram notes, prompts "stimulation." Engaging the students in a collective process peaked their interest and motivated them to engage with the text, which, in turn, resulted in better reading and understanding. Milgram detected that fears of embarrassment over pronunciation errors were very much reduced when students read aloud in unison, promoting a greater commitment to sense-making in the classroom structure. The comfort of mastering the more technical aspects of reading like punctuation and intonation through a group activity enabled students to approach learning talmudic content more confidently.

Differing from Milgram, whose pedagogical methodology echoed an ancient and medieval mode of reading, Sarra Lev aimed to create a new mode of reading the Talmud — reading for the formation of a more ethical society in her chapter, "Talmud that Works Your Heart: New Approaches to Reading." Drawing from the work of Hans Georg Gadamer and theorists of transformational learning, Lev articulates a methodology where reading the Talmud—even its more difficult texts—-becomes a summons to interpret it and a summons to holiness. The Talmud does not tell us what it means to be holy but, rather, impels us toward holiness through our interactions with its texts - that is, its many voices. Lev's chapter thereby proposes a model where students learn to read the Talmud as a summons; they come to read with their minds and with their hearts, cultivating empathy. 


\section{Conclusion}

As our work makes clear, learning to read Talmud is a complex and multifaceted endeavor. It involves the mastery of base-line skills: learning the technical terminology and the particular dialogical style of argument for which the Talmud is well-known. But, as this book argues, learning to read Talmud is more than either of these two abilities. Making sense of the Talmud-whether in its original language or in translation-involves competencies in several cognitive processes: breaking a sugya into much smaller units in order to rebuild sense; simultaneously considering multiple answers as possible; viewing problems as integral to the text; integrating the ahistorical with the historical; becoming conscious of and rethinking prior religious, cultural and historical assumptions in the face of new evidence; learning to think with a different mode of reasoning; building bridges between the ancient and the contemporary; and confronting the unethical. Interestingly, in the end, we found that each author, while equally dedicated to teaching their students to read for meaning, whether in the seminary or secular university, emphasized different avenues of achieving this goal; each accentuated different interpretive methods. And despite their differences, each teacher agreed that a student learns more about the Talmud by including in the pedagogical process learning how to read the Talmud (even in translation).

And yet, behind this goal of searching for meaning lay an implicit question: Why study Talmud at all? ${ }^{36}$ As we taught, each of us was aware that for many of our students studying this text is not a given; the value of investing in continued Talmud study was not always self-evident. Indeed, for some students, the course we taught may be the only one in which they would formally study Talmud. However, each teacher, through a chosen method of reading, aimed to help students answer the question, "Why study Talmud?" For one teacher, the "why of reading" lay in the value of creating a life-long Jewish practice of study; for another, the "why" lay in becoming a better

36 For a number of personal answers to this question, see Paul Socken, ed., Why Study Talmud in the Twenty-First Century? The Relevance of the Ancient Jewish Text to Our World (Lanham, MD: Lexington Books, 2009). 
historian of antiquity; and for still another, it lay in helping to envision a more ethical society. Yet, whether the goal is a deeper understanding of a particular sugya, connecting the Talmud with the discipline of the humanities, rooting oneself in a chain of tradition, or understanding that one's personhood is simultaneously constrained by context and inherently imaginative-we knew that we wanted our students to learn how to read richly and rigorously. Our students may not answer the question, "Why study Talmud?" in the same ways that we do. But only through entering the world of the Talmud by reading it deeply and thoroughly will our students begin to answer the question for themselves, "Why study Talmud?" 